\title{
Comparison of the diagnostic efficacy and complications of transbronchial biopsy in elderly and young patients
}

\author{
Sibel GÜNAY ${ }^{1}(I D)$ \\ Nilgün DEMiRCi² ${ }^{(I D)}$ \\ Melahat UZEL \\ ŞENER $^{3}$ (ID) \\ Ceyda ANAR ${ }^{4}$ (ID) \\ Feyza Merve SEKKIN \\ SINICI $^{5}$ \\ Zarifa ACHIKGOZ ${ }^{2}$ (ID) \\ Melike YÜKSEL \\ YAVUZ $^{4}($ ID) \\ Aydın BALCI ${ }^{5}(I D)$ \\ Ersin GÜNAY $^{5}(I D)$
}

\author{
${ }^{1}$ Clinic of Chest Diseases, Afyonkarahisar State Hospital, \\ Afyonkarahisar, Turkey \\ ${ }^{1}$ Afyonkarahisar Devlet Hastanesi, Göğüs Hastalıkları Kliniği, \\ Afyonkarahisar, Türkiye \\ 2 Department of Chest Diseases, Gazi University Faculty of Medicine, \\ Ankara, Turkey \\ ${ }^{2}$ Gazi Üniversitesi Tıp Fakültesi, Göğüs Hastalıkları Anabilim Dalı, \\ Ankara, Türkiye \\ ${ }^{3}$ Clinic of Chest Diseases, Atatürk Chest Diseases and Thoracic Surgery \\ Training and Research Hospital, Ankara, Turkey \\ ${ }^{3}$ Atatürk Gögüs Hastalıkları ve Gögüs Cerrahisi Eğitim ve Araştırma \\ Hastanesi, Gögüs Hastalıkları Anabilim Dalı, Ankara, Türkiye \\ ${ }^{4}$ Clinic of Chest Diseases, İzmir Suat Seren Chest Diseases and Thoracic \\ Surgery Training and Research Hospital, İzmir, Turkey \\ ${ }^{4}$ Izmir Suat Seren Gögüs Hastalıkları ve Göğüs Cerrahisi Ĕ̆itim ve \\ Araştırma Hastanesi, Göğüs Hastalıkları Kliniği, İzmir, Türkiye \\ ${ }^{5}$ Department of Chest Diseases, Afyonkarahisar Health Sciences University \\ Faculty of Medicine, Afyonkarahisar, Turkey \\ ${ }^{5}$ Afyonkarahisar Sağlık Bilimleri Üniversitesi Tıp Fakültesi, Göğüs Hastalıkları \\ Anabilim Dalı, Afyonkarahisar, Türkiye
}

Cite this article as: Günay S, Demirci N, Uzel Şener $M$, Anar C, Sekkin Sınıc FM, Achikgoz Z et al. Comparison of the diagnostic efficacy and complications of transbronchial biopsy in elderly and young patients. Tuberk Toraks 2021;69(2):153-159.

Yazışma Adresi (Address for Correspondence)

\section{Dr. Ersin GÜNAY}

Afyonkarahisar Sağlık Bilimleri Üniversitesi Tıp Fakültesi, Göğüs Hastalıkları Anabilim Dalı,

AFYONKARAHISAR - TÜRKIYE

e-mail: ersingunay@gmail.com

\footnotetext{
CCopyright 2021 by Tuberculosis and Thorax.
}

Available on-line at www.tuberktoraks.org.com

\section{ABSTRACT}

Comparison of the diagnostic efficacy and complications of transbronchial biopsy in elderly and young patients

Introduction: Among bronchoscopic procedures, transbronchial biopsy (TBB) is considered a high-risk procedure. In this study, we aimed to investigate the indications, diagnostic efficacy and complications of TBB in the elderly, which is accepted as a sensitive group.

Materials and Methods: The study was designed as a multicenter retrospective observational study. Data of 4226 patients who underwent diagnostic bronchoscopy were scanned for this study. 791 patients who underwent transbronchial biopsy were included in this study. All patients were evaluated in terms of lung regions, diagnosis, and complications.

Results: A total of 791 patients, 329 (41.6\%) female patients, who underwent TBB were included in the study. Mean age of the patients was $54.54 \pm 14.94$ years. The most common indications were ILD (45.6\%), malignancy $(24.0 \%)$ 
and sarcoidosis $(9.9 \%)$. Mean age of the elderly patients $(n=263)$ was $69.89 \pm 4.83$ years, and mean age of the young patients ( $n=$ 528 ) was $46.90 \pm 11.28$ years $(p<0.001)$. In both age groups, the most common indication was ILD. Complications developed during and after the procedure in 51 of the young patients $(9.7 \%)$ and in 21 of the elderly $(8.0 \%)(p=0.441)$. The most common complication was pneumothorax with $4.6 \%$ in the elderly, and pneumothorax with $5.9 \%$ in the young $(p=0.441)$. The most common diagnosis was malignancy $(12.2 \%)$ in the elderly, as the most common diagnosis was malignancy $(7.2 \%)$ in the young $(p=0.020)$. While anthracosis, ILD and organized pneumonia were the other common diagnoses in the elderly, sarcoidosis, anthracosis and organized pneumonia were the other common diagnoses in the young. The diagnosis of sarcoidosis was achieved more frequently in the young $(6.6 \%)$ than in the elderly $(0.8 \%)(p<0.001)$.

Conclusion: Transbronchial biopsy can be performed safely in elderly patients, with similar diagnostic success and complication rates to younger patients.

Key words: Elderly; complication; interstitial lung diseases; lung cancer; TBB; bronchoscopy

\section{ÖZ}

\section{Yaşlı ve genç hastalarda transbronşiyal biyopsinin tanısal etkinliğinin ve komplikasyonlarının karşılaştırılması}

Giriş: Bronkoskopik işlemler arasında transbronşiyal biyopsi (TBB) yüksek riskli işlem olarak kabul edilmektedir. Bu çalışmada hassas bir grup olan yaşlılarda TBB'nin endikasyonlarını, tanısal etkinliğini ve komplikasyonlarını araştırmayı amaçladık.

Materyal ve Metod: Çalışma retrospektif çok merkezli gözlemsel bir çalışma olarak dizayn edildi. Çalışma için tanısal bronkoskopi yapılan 4226 hastanın verisi tarandı. Transbronşiyal biyopsi yapılan 791 hasta çalışmaya dahil edildi. Tüm hastalar örneklenen akciğer bölgeleri, tanıları ve komplikasyonlar açısından değerlendirildi.

Bulgular: Çalışmaya TBB uygulanan, $329(\% 41,6)$ kadın hastanın bulunduğu toplam 791 hasta dahil edildi. Hastaların yaş ortalama-

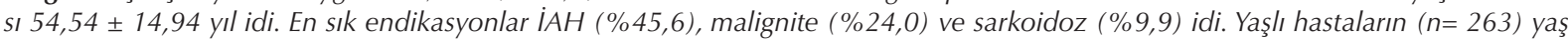
ortalaması 69,89 $\pm 4,83$ yıl, genç hastaların $(n=528)$ yaş ortalaması 46,90 $\pm 11,28$ yıldı $(p<0,001)$. Her iki yaş grubunda da en sık endikasyon IAH idi. Genç hastaların 51'inde (\%9,7), yaşlıların ise 21 'inde $(\% 8,0)$ işlem esnasında ve sonrasında komplikasyon gelişti $(p=0,441)$. En sık komplikasyon yaşlılarda \% 4.6 ile pnömotoraks iken gençlerde \%5,9 ile pnömotorakstı $(p=0,441)$. Yaşlılarda en sık konulan tanı malignite $(\% 12,2)$ iken gençlerde de en sık malignite $(\% 7,2)$ tanısı konuldu $(p=0,020)$. Yaşlılarda antrakoz, iAH ve organize pnömoni diğer en sık tanılar iken gençlerde sarkoidoz, antrakoz ve organize pnömoni en sık tanılardı. Tanı oranları karşılaştırıldığında gençlerde sarkoidoz tanısının $(\% 6,6)$ yaşlılardan $(\% 0,8)$ daha sık konulduğu $(p<0,001)$ görüldü.

Sonuç: Transbronşiyal biyopsi, yaşlı hastalarda da genç hastalardakine benzer tanısal başarı ve komplikasyon oranlarıyla güvenli bir şekilde uygulanabilir.

Anahtar kelimeler: Yaşı; komplikasyon; interstisyel akciğer hastalıkları; akciğer kanseri; TBB; bronkoskopi

\section{INTRODUCTION}

Mortality rates decrease due to advances in early diagnosis methods and treatment options, and consequently, an increase in the number of elderly population is observed $(1,2)$. As the proportion of elderly people increases in the society, an increase in individuals with comorbid diseases is inevitable. In addition to age-related comorbid diseases and complex treatments, these patients constitute a difficult group of patients for the clinicians because of the accompanying atypical clinical findings and impaired cognitive functions. In this case, it reveals the need for low-risk diagnostic procedures for elderly patients to reach early treatment.

Fiberoptic bronchoscopy (FB) is a gold standard minimally invasive diagnostic and therapeutic method that allows the evaluation of all lower respiratory tract starting from the trachea. Common procedures performed with bronchoscopy are bronchial biopsies, bronchoalveolar lavage, transbronchial biopsies (TBB) and needle aspirations. In addition, it can be applied with FB in some endobronchial treatments. Limited number of studies have investigated the safety of these methods in the elderly population (3-8). TBB is a bronchoscopic diagnostic procedure that is frequently used in the diagnosis of lung tumors involving the lung periphery and parenchyma, as well as interstitial lung diseases (ILD), sarcoidosis and tuberculosis with extensive lung parenchymal involvement. TBB is accepted as a high-risk procedure among bronchoscopic procedures (9). Although there are a limited number of studies on the use of other bronchoscopic procedures in the elderly population in the literature, no studies have been reported on TBB application, which has a high complication rate, especially in elderly patients. In this study, we aimed to investigate the indications, diagnostic value and complications of TBB applied in the elderly population. 


\section{MATERIALS and METHODS}

The study was designed as a retrospective multicenter observational study. For the study, the data of 4226 patients who underwent diagnostic bronchoscopy within 4 years (January 2016 and December 2019) were scanned. 791 patients who underwent TBB were included in the study. Patients who underwent bronchoscopy in the bronchoscopy suit or intensive care unit were included in the study. In all procedures, patients were administered local anesthesia (lidocaine spray $10 \mathrm{mg} /$ dose) and conscious sedation (midazolam i.v. started with $1 \mathrm{mg}$ and $1 \mathrm{mg}$ midazolam was added at 5-minute intervals as needed). During the procedure, the patients were followed up with cardiopulmonary monitoring including pulse rate, oxygen saturation, blood pressure and electrocardiography. Complete blood counts (platelet> $50.000 / \mathrm{mm}^{3}$ ) and blood biochemical analysis (blood urea nitrogen $<30 \mathrm{mg} / \mathrm{dl}$ ) were performed in all patients who were planned to undergo TBB. In patients using antiplatelet agents, the drug was discontinued at least 5 days before the procedure. TBB procedures of the patients were performed according to the localization of the lesion observed on thorax computed tomography scan. None of the procedures were performed under fluoroscopy guidance. Sampling was made only from the one-sided lung parenchyma. 5-7 times sampling was performed in each biopsy procedure. Rapid on-site cytological examination (ROSE) was not applied in any clinic participating in the study. Control chest radiographs of all patients were obtained within 1-2 hours of the procedure and the patients were evaluated for pneumothorax and other complications. The indications, complications of the procedure, the need for tube thoracostomy in patients with pneumothorax occurred and pathological results were evaluated. Bleeding was evaluated as minor (less than $50 \mathrm{ml}$ and/or controlled with cold saline or adrenaline application) and major hemorrhage (more than 50 $\mathrm{ml}$ ).

\section{Statistical Analysis}

Statistical analysis was performed using SPSS (PASW Statistics for Windows, Version 18.0; SPSS Inc., Chicago, IL, USA). Patient characteristics were defined using the ratio for categorical variables and the mean for continuous variables. The patients were divided into two groups as elderly (65 years and older) and younger (under 65 years). The rates of data regarding indications, complications and diagnoses of the patients in both groups were compared using the chi-square test. When the frequency was below 5, proportional comparisons were made using Fisher's exact test of probability. Student's t test was used to compare the mean ages of both groups. $\mathrm{P}$ value $<0.05$ was set as significant.

\section{RESULTS}

A total of 791 patients, who underwent TBB, were included in the study. Of them, 329 patients (41.6\%) were females. Mean age of all patients was $54.54 \pm$ 14.94 years. The most common indications were ILD $(45.6 \%)$, malignancy $(24.0 \%)$ and sarcoidosis $(9.9 \%)$. While TBB was performed mostly from the right lung $(74.7 \%)$, the most common sampling side was the lower lobes $(65.0 \%)$. The most common complications were pneumothorax $(5.4 \%)$ and minor hemorrhage $(2.7 \%)$. Respiratory failure and death did not occur in any patients (Table 1 ).

Mean age of the elderly patients $(n=263)$ was 69.89 \pm 4.83 years, and mean age of the young patients $(\mathrm{n}=$ $528)$ was $46.90 \pm 11.28$ years $(p<0.001)$. While $44.9 \%(n=237)$ of the patients in "the young patient group" were females, the rate of females in the elderly patients was $35.0 \%(n=92)$. The most common indication was ILD in both groups. Malignancy indication was more common in elderly patients (36.9\% vs. $17.6 \% ; p<0.001)$, while sarcoidosis was found to be more common in young people $(12.5 \%)$ than in the elderly $(4.6 \%)(p<0.001)$ (Table 2). Complications developed during and after the procedure in 51 of the young patients $(9.7 \%)$ and in 21 of the elderly $(8.0 \%)(p=0.441)$.

Complications developed in $51(9.7 \%)$ of the younger patient group and in $21(8.0 \%)$ of the elderly patients $(p=0.441)$. The most common complication was pneumothorax with $4.6 \%$ in the elderly patients, and pneumothorax with $5.9 \%$ in the young patients $(p=0.441)$. Death or respiratory failure was not detected in any of the patients. All bleeding was evaluated as minor hemorrhage. Other complication rates were found to be similar in both groups (Table 2).

The most common diagnosis was malignancy both in the elderly $(12.2 \%)$, and in the young patient groups $(7.2 \%)(p=0.020)$. While anthracosis, ILD and organized pneumonia were the other most common diagnoses in the elderly, sarcoidosis, anthracosis and 
Table 1. Demographic information of all patients, bronchoscopy indications, complications and distribution of anatomic regions where transbronchial biopsy was performed

\begin{tabular}{|lcc|}
\hline Parameters & N & $\%$ \\
\hline Age, year, Mean \pm SD & $54.54 \pm 14.94$ & 41.6 \\
Sex, Female (\%) & 329 & 45.6 \\
Indications & & 24.0 \\
Interstitial lung diseases & 361 & 9.9 \\
Malignancy & 190 & 8.3 \\
Sarcoidosis & 78 & 4.9 \\
Tuberculosis & 66 & 7.2 \\
Organizing pneumonia & 39 & 9.1 \\
Others & 57 & 5.4 \\
Complications & 72 & 2.7 \\
Pneumothorax & 43 & 0.6 \\
Haemorrhage & 21 & 0.4 \\
Desaturation & 5 & 0 \\
Cardiac arrythmia & 3 & 0 \\
Respiratory insufficiency & 0 & \\
Death & 0 & 74.7 \\
Biopsy localization & & 25.3 \\
Right lung & 591 & 21.2 \\
Left lung & 200 & 65.0 \\
Upper lobe & 168 & 13.8 \\
Lower lobe & 514 & \\
Middle lobe & 109 & \\
\hline
\end{tabular}

Table 2. Demographic information, indications, complications for transbronchial biopsy by age groups

\begin{tabular}{|c|c|c|c|c|c|}
\hline \multirow[b]{2}{*}{ Parameters } & \multicolumn{2}{|c|}{ Young Patients } & \multicolumn{2}{|c|}{ Elder Patients } & \multirow[b]{2}{*}{$\mathbf{p}$} \\
\hline & $\mathbf{n}$ & $\%$ & $\mathbf{n}$ & $\%$ & \\
\hline Age, year, Mean $\pm S D$ & $46.90 \pm 11.28$ & & $69.89 \pm 4.83$ & & $<0.001$ \\
\hline Sex, Female (\%) & 237 & 44.9 & 92 & 35.0 & 0.008 \\
\hline \multicolumn{6}{|l|}{ Indications } \\
\hline Interstitial lung diseases & 245 & 46.4 & 116 & 44.1 & 0.542 \\
\hline Malignancy & 93 & 17.6 & 97 & 36.9 & $<0.001$ \\
\hline Sarcoidosis & 66 & 12.5 & 12 & 4.6 & $<0.001$ \\
\hline Tuberculosis & 47 & 8.9 & 19 & 7.2 & 0.422 \\
\hline Organizing pneumonia & 27 & 5.1 & 12 & 4.6 & 0.736 \\
\hline Others & 50 & 9.5 & 7 & 2.7 & $<0.001$ \\
\hline Complications & 51 & 9.7 & 21 & 8.0 & 0.441 \\
\hline Pneumothorax & 31 & 5.9 & 12 & 4.6 & 0.444 \\
\hline Haemorrhage & 15 & 2.8 & 6 & 2.3 & 0.645 \\
\hline Desaturation & 3 & 0.6 & 2 & 0.8 & 0.748 \\
\hline Cardiac arrythmia & 2 & 0.4 & 1 & 0.4 & 0.998 \\
\hline Respiratory insufficiency & 0 & 0 & 0 & 0 & \\
\hline Death & 0 & 0 & 0 & 0 & \\
\hline Patients who underwent tube thoracostomy* & 17 & 54.8 & 5 & 41 & 0.438 \\
\hline
\end{tabular}


organized pneumonia were the most common diagnoses in the young. It was seen that the diagnosis of sarcoidosis was made more frequently in young people $(6.6 \%)$ than in the elderly $(0.8 \%) \quad(p<0.001)$ (Table 3).

When the rates of malignancy diagnoses made in the patients were compared, it was found that the diagnosis of adenocarcinoma was the most common diagnosis with TBB in both age groups $(51.4 \%$ in the elderly, $55.3 \%$ in the young; $p=0.484)$. Other diagnosis rates were also found at similar rates in both groups (Table 4).

\section{DISCUSSION}

The most important outcome of our study is that TBB has similar diagnostic efficiency in the elderly and young people. No major complications such as respiratory failure and death were encountered in either age group. Other complications were reported at similar rates in the two groups. These findings show that TBB, which is used as a diagnostic bronchoscopic method, should not be avoided in elderly patients due to undesirable risks related to age in the presence of appropriate indications.

Table 3. Diagnosis rates of patients by age group*

\begin{tabular}{|c|c|c|c|c|c|}
\hline & \multicolumn{2}{|c|}{ Young Patients } & \multicolumn{2}{|c|}{ Elderly Patients } & \multirow[b]{2}{*}{ p } \\
\hline & $\mathbf{n}$ & $\%$ & $\mathbf{n}$ & $\%$ & \\
\hline Lung malignancies & 38 & 7.2 & 32 & 12.2 & 0.020 \\
\hline Sarcoidosis & 35 & 6.6 & 2 & 0.8 & $<0.001$ \\
\hline Anthracosis & 32 & 6.1 & 17 & 6.5 & 0.825 \\
\hline Organizing pneumonia & 26 & 4.9 & 10 & 3.8 & 0.476 \\
\hline Interstitial lung diseases (including UIP pattern) & 19 & 3.6 & 11 & 4.2 & 0.685 \\
\hline Tuberculosis & 3 & 0.6 & 2 & 0.8 & 0.748 \\
\hline Unidentified granulomatous diseases & 14 & 2.7 & 3 & 1.1 & 0.161 \\
\hline Hypersensitivity pneumonia & 9 & 1.7 & 2 & 0.8 & 0.285 \\
\hline Eosinophilic pneumonia & 7 & 1.3 & 3 & 1.1 & 0.826 \\
\hline Hemosiderosis & 5 & 0.9 & 2 & 0.8 & 0.792 \\
\hline Pulmonary langerhans cell histiocytosis & 3 & 0.6 & 0 & 0 & 0.221 \\
\hline Pulmonary alveolar microlithiasis & 3 & 0.6 & 1 & 0.4 & 0.726 \\
\hline Others & 6 & 1.1 & 3 & 1.1 & 0.996 \\
\hline
\end{tabular}

Table 4. Distribution of malignancy diagnoses made by transbronchial biopsy by age groups *

\begin{tabular}{|c|c|c|c|c|c|}
\hline \multirow[b]{2}{*}{ Types of tumors } & \multicolumn{2}{|c|}{$\begin{array}{l}\text { Younger Patients } \\
\qquad(\mathrm{n}=38)\end{array}$} & \multicolumn{2}{|c|}{$\begin{array}{l}\text { Elder patients } \\
\qquad(\mathrm{n}=32)\end{array}$} & \multirow[b]{2}{*}{$\mathbf{p}$} \\
\hline & $\mathbf{n}$ & $\%$ & $\mathbf{n}$ & $\%$ & \\
\hline Adenocarcinoma & 21 & 55.3 & 15 & 51.4 & 0.484 \\
\hline Squamous cell carcinoma & 4 & 10.5 & 8 & 25.0 & 0.112 \\
\hline Small cell carcinoma & 3 & 7.9 & 2 & 6.2 & 0.792 \\
\hline Non-small cell carcinoma (Unclassified) & 3 & 7.9 & 2 & 6.2 & 0.792 \\
\hline Lymphoma & 1 & 2.6 & 0 & 0 & 0.359 \\
\hline Untypable & 6 & 15.8 & 5 & 15.6 & 0.985 \\
\hline
\end{tabular}


Flexible bronchoscopy (FB) is a diagnostic and therapeutic procedure that can be used safely in young patients as well as in elderly patients (3-7). Transbronchial biopsy is a diagnostic bronchoscopic method used in diseases involving the lung parenchyma and peripheral lung lesions. TBB has high diagnostic yield for sarcoidosis, pulmonary Langerhans cell histiocytosis (PLHH), pulmonary alveolar proteinosis (PAP), granulomatous lung diseases such as tuberculosis, P. jirovejii pneumonia (PJP), malignancies and occupational/environmental lung diseases (silicosis, anthracosis) (10-12). It is stated that the diagnostic efficiency of the use of transbronchial cryobiopsy is higher, especially in the diagnosis of ILD (such as usual interstitial pneumonia (UIP), desquamative interstitial pneumonia), since larger biopsy samples can be taken $(13,14)$. In addition, TBB can be applied under the guidance of the radial probe EBUS in the diagnosis of peripheral lesions (15). However, transbronchial cryobiopsies and TBBs taken under the guidance of EBUS were not included in our study. The most common indications for TBB in our study were ILDs, lung tumors, sarcoidosis and tuberculosis, as reported in the literature. Especially in elderly patients, it was observed that the most common indication following the ILDs was malignancies.

The diagnostic role of TBB in ILD is varying. While TBB is more preferable in some granulomatous ILDs, larger tissue samples are required in others for differential diagnosis. TBB has limited diagnostic efficacy especially in the diagnosis of ILD with UIP pattern. Mostly, TBB is used to exclude other possible alternative diagnoses (such as malignancy, infections, sarcoidosis, eosinophilic pneumonia, PLHH, organized pneumonia) in the diagnosis of idiopathic pulmonary fibrosis (IPF) (12). TBB is the recommended diagnostic method in the diagnosis of sarcoidosis due to widespread parenchymal involvement. The diagnostic yield depends largely on the experience of the bronchoscopist and varies between $40-90 \%(12,16)$. TBB is also used in the diagnosis of peripheral lung malignancies and tumors with diffuse parenchymal infiltration (lymphangitic spread or lepidic pattern adenocarcinoma) (12). In our study, malignancy was the most frequent diagnosis in both elderly and young patients. The rate of malignancy was significantly higher in the elderly patients than in the young patients. More than $50 \%$ of the patients in both groups were diagnosed with adenocarcinoma.
Squamous cell carcinoma and small cell carcinoma followed the diagnosis of adenocarcinoma. Sarcoidosis, anthracosis, organized pneumonia and UIP pattern was outlined in both age groups.

The most common complications after TBB procedure are pneumothorax and bleeding. There is a risk of mortality, especially when bilateral biopsies are applied. Therefore, unilateral biopsies should be confidently preferred. For the evaluation of the pneumothorax, it is recommended to be checked by chest radiography after the procedure. Rarely, cardiac arrhythmia, desaturation, persistent cough, pneumomediastinum, and air embolism have been reported (7,9-12,17-19). Complications were evaluated in detail in this study. Complication rates in both groups were similar $(9.7 \%$ in the young patient group and $8.0 \%$ in the elderly patient group $(p=0.441)$. Pneumothorax is the most common complication in both groups. Despite the presence of comorbid diseases and regular drug use in elder patients, bleeding complications were also found at a similar rate in both groups. In our study, chest radiography was obtained from all biopsy patients after the procedure for pneumothorax evaluation. However, in the study of Izbicki et al. , it was stated that there is no need for control chest X-ray in asymptomatic patients or in patients without desaturation after TBB (19).

There are several limitations in our study. First, the study design is retrospective. Second, although the early complications within the first 24 hours were recorded, late complications after 24 hours were not taken into account. The strongest aspect of our study is that this is the first study evaluating the diagnostic efficacy and complications of TBB, which has the highest complication risk among other bronchoscopic procedures, in the elderly population.

In conclusion, the elderly population is a vulnerable population due to the use of a wide variety of treatments and comorbidities that may increase the risk of complications. In our study, the same diagnostic success was achieved in elderly patients as in younger patients without increasing the risk of complications. Therefore, TBB procedure can be applied safely in elderly patients by making necessary preliminary preparations and taking medical precautions in the presence of appropriate indications.

Ethical Committee Approval: Ethics committee approval (720/2021) for the study was obtained from Ankara Atatürk Chest Diseases and Thoracic Surgery 
Training and Research Hospital Clinical Research Ethics Committee.

\section{CONFLICT of INTEREST}

The authors of this research article declare that they have no conflict of interest.

\section{AUTHORSHIP CONTRIBUTIONS}

Concept/Design: SG, EG, ND

Analysis/Interpretation: EG

Data Acquisition: ND, MUŞ, CA, FMSS, ZA, MYY, $A B, E G$

Writing: SG

Clinical Revision: EG, ND

Final Approval: SG, ND, MUŞ, CA, FMSS, ZA, MYY, $A B, E G$

\section{REFERENCES}

1. Population ageing and sustainable development. Available from: https://www.un.org/en/development/desa/population/publications/pdf/popfacts/PopFacts_2017-1.pdf (Accessed date: 3 March 2021)

2. Mandıracıoğlu A. Dünyada ve Türkiye'de yaşlıların demografik özellikleri. Ege Tip Dergisi 2010; 49(3): 39-45S.

3. McLaughlin CW, Skabelund AJ, Easterling ER, Morris MJ. The Safety and utility of fiberoptic bronchoscopy in the very elderly. J Bronchology Interv Pulmonol. 2018; 25(4): 300-4.

4. Noda N, Hara M, Ise S, Ose M, Tatsuta M, Nagaoka A, et al. Comfort and safety of bronchoscopy performed under sedation and local anesthesia in elderly patients. Medicine (Baltimore) 2020; 99(43): e22561.

5. Mondoni $M$, Radovanovic D, Sotgiu G. Interventional pulmonology techniques in elderly patients with comorbidities. Eur J Intern Med 2019; 59: 14-20.

6. Haga T, Cho K, Nakagawa A, Takagiwa J, Arakawa S, Sakamoto Y, et al. Complications of fiberoptic bronchoscopy in very elderly adults. I Am Geriatr Soc 2016; 64(3): 676-7.

7. Sarinc Ulasli S, Gunay E, Akar O, Halici B, Koyuncu T, Unlu M. Diagnostic utility of flexible bronchoscopy in elderly patients. Clin Respir J 2014;8(3):357-63.
8. Yılmaz Demirci N, Öztürk C. Diagnostic utility of endobronchial ultrasound-guided transbronchial needle aspiration in elderly patients. Tuberk Toraks 2018; 66(2): 115121.

9. Abuqayyas S, Raju S, Bartholomew JR, Abu Hweij R, Mehta AC. Management of antithrombotic agents in patients undergoing flexible bronchoscopy. Eur Respir Rev 2017; 26(145): 170001.

10. Mohan A, Madan K, Hadda V. Guidelines for diagnostic flexible bronchoscopy in adults: Joint Indian Chest Society/ National College of chest physicians (I)/Indian association for bronchology recommendations. Lung India 2019; 36(Supplement): S37-S89.

11. Descombes E, Gardiol D, Leuenberger P. Transbronchial lung biopsy: an analysis of 530 cases with reference to the number of samples. Monaldi Arch Chest Dis 1997; 52: 324-9.

12. Ibrahim AS, Allangawi MH, Sattar HA. Indications, diagnostic yields and complications of transbronchial biopsy over 5 years in the State of Qatar. Saudi Med J 2005; 26(4): 641-5.

13. Keenan J, Backer E, Gibson H, et al. Transbronchial lung cryobiopsy in the diagnosis of interstitial lung disease. Tuberk Toraks 2019; 67(4): 300-6.

14. Casoni GL, Cordeiro CR Jr, Tomassetti S, Romagnoli M, Chilosi M, Cancellieri A, et al. The role of transbronchial biopsy in the diagnosis of diffuse parenchymal lung diseases: pro. Rev Port Pneumol 2012; 18(2): 57-60.

15. Kurimoto N, Miyazawa T, Okimasa S, Maeda A, Oiwa $H$, Miyazu $Y$, et al. Endobronchial ultrasonography using a guide sheath increases the ability to diagnose peripheral pulmonary lesions endoscopically. Chest 2004; 126: 95965.

16. Gilman MJ, Wang KP. Transbronchial lung biopsy in sarcoidosis. An approach to determine the optimal number of biopsies. Am Rev Respir Dis 1980; 122: 721-4.

17. Moreira-Silva S, Urbano J, Rocha G, Braz V. Subcutaneous emphysema and pneumomediastinum as rare complications of transbronchial biopsy. BMJ Case Rep 2016 Jan 5;2016:bcr2015213623.

18. Evison M, Crosbie PA, Bright-Thomas R. Cerebral air embolism following transbronchial lung biopsy during flexible bronchoscopy. Respir Med Case Rep 2014; 12: 39-40.

19. Izbicki G, Romem A, Arish N. avoiding routine chest radiography after transbronchial biopsy is safe. Respiration 2016; 92(3): 176-81. 